\title{
The self-confidence on Local Cultural and The value of Documentary -Analysis on Jiayuguang international short film festival
}

\author{
Zhang xi \\ Art Institute of Lanzhou Jiaotong University 730070
}

\begin{abstract}
Jiayuguang international short film festival permeates confidence on Chinese Culture and pursues a spring of documentary, which will construct a imaging platform for cultural industries. Qinghai Mountain Documentary Festival focus on "Mountain" eco-cultural concept. Guangzhou International Documentary Festival is characterized by operation of the market. However Jiayuguang international short film festival has unique historical background and international perspective on the Silk Road. It also has subject and aesthetic characteristics of chinese western culture. Now, It will clear cultural affiliation, create a professional documentary production chain, and innovate industrial operations.
\end{abstract}

Key word: Jiayuguang international short film festival Background Positioning Development Trend

\section{INTRODUCTION}

Background and Significance of China Jiayuguan International Short Film Festival

The film industry is the core of the cultural industry, which is the most influential subclass, the best integral platform, the main force to participate in international competition. In recent years, documentaies have enhanced the cultural quality of television programs and audiences. Heritage and international of chinese western cultural, become the basis for the development of documentary. Jiayuguan International Short Film Festival, carries confidence on Chinese Culture and pursues a spring of documentary.

\subsection{Image expression: The core of cultural industries}

Film and television industry is one important type of 9 types in cultural industries, which is both content and media. Hollywood, India's Bollywood, Korean Cultural
Industry Development Institute all create a country's soft power by a huge effect of film and television industry. Under the macro conditions of Cultural development, Gansu Province made the goal of building cultural province and the target of Chinese Civilization Innovation Zone . Implementation Opinions of Documentary construction in Gansu province proposed a target that documentaries will focus on the overall goal " Gansu theme, Chinese western style, Chinese elements, the world's expression ". 86 themes are selected initially in september 2013. There were 485 documentary's topics on account.[1]Such themes resources of film and television urgently need open up by China Jiayuguan International Short Film Festival.

1.2 The Value of Documentary: the spring of documentary film industry

While these documentaries, such as Imperial palace(2003), Rise of Great Powers(2003),Dunhuang(2010), A Bite of China I (2012), A Bite of China $I I(2014$,$) come into TV screens, they$ were not shelved precious relics, but a kind of mass culture. On January 1, 2011, CCTV-9 became the first national documentary channel. Chinese Documentary overseas exported 22 million yuan, accounted for $14 \%$ of film culture in 2012. CCTV-9 brought $180 \%$ growth in overseas sales in 2012 , the total amount exceeded $\$ 2,480,000$. 'Chinese documentary production and communication Union Alliance " established in 2013 broadcasts a 30- minutes program " record in China" every day, which included more than 100 production facilities and 90 provincial and municipal TV stations. Otherwise, the policy that each satellite TV channels should broadcast documentary at least 30 minutes a day in 
2014 , urgently need 6000 hours documentary .

42 indie documentaries made by Gansu Province were broadcasted by CCTV recently. Qinchuan working at Jiuquan TV and his term created 8 documentaries(including 33 piece s). These works were all communicated by CCTV. We called this phenomenon as "Jiuquan documentary creation". Some documentaries which were associated with intangible cultural heritage protection played a great role in Gansu anthropological study, such as Flowers -Northwest folk directed by Mengziwie. Secondly, local TV Columns about documentary, such as Lanzhou TV's " Lanzhou past" and Tianshui TV's " humanistic Tianshui ", have been writing everyday local life and forming a stable structure on Gansu documentary. Last but not least, historic and international themes, such as revolution theme, Dunhuang theme, ancestor theme were excavated by many television agencies. For example, around Dunhuang theme, these were Dunhuang, Dunhuang calligraphy, Dunhuang fairy, and so on. Dunhuang was particularly worth mentioning, which was a typical documentary because of its success on overseas sale. Under the national policy support and market demand boost, the documentary showed a spurt of development momentum.

\subsection{Cultural self-confidence : the essence of Chinese Western culture}

Chinese western cultural resources can support Chinese future cultural industry. Chen li an, an economic analyst, divided Gansu cultural into six kinds which were ancient culture, traditional Culture, open culture, immigrant culture, modern culture and node culture. [2]

All kinds of culture compose chinese civilization. Because of this, the State Council approved the construction of Chinese Civilization Innovation Zone, which was the only national strategic platform in the province as a unit, in Gansu Province in 2013. The cultural self-confidence is the core of tradition and innovation, the base of China Jiayuguan International Short Film Festival.

\section{Postion of China Jiayuguan International Short Film Festival.}

\subsection{Introduction of China Jiayuguan International Short Film Festival.}

China Jiayuguan International Short Film Festival was co-sponsored by the State Press and Publication Administration of Radio and Gansu Provincial People's Government. The first

exhibition's subject was "integrating short film resources at home and abroad, building a platformfor exhibition and exchange, promoting cultural and cultural industries exchange and cooperation, promoting Gansu culture to the world "(2012).400 works, coming from more than 10 counties, such as Russia, UK, USA, joined in this exhibition.70 short films were projected onto the screen.23 short films won awards. There were 35 Gansu theme documentaries, which were concentrated on the local style.

The second exhibition, with the theme of "Let the world know Gansu , let Gansu come to the world" in 2013, designed to create a professional, academic, high-end forum brand well-knowed by the domestic and the world. A grand goal of construction of the documentary manufacture province was proposed in this exhibition. There were 20 documentaries produced by Gansu ,which was worthy in creating a brand of Gansu documentary . The third exhibition considered "Silk image" as the theme in 2014.500 works showed the civilization of Silk Road.25 documentaries produced by Gansu, entered into the market.

Three exhibitions gained good effects. The idea of exhibition's development is more and more detailed, from diverse cultures to interpretation of the main theme, from a single event to market demand.

\subsection{The core competitiveness of internal documentary Film Festival}

2.2.1Mountain theme : the secret of China ( Qinghai ) World Mountain Documentary Festival

China ( Qinghai ) World Mountain Documentary Festival was co-sponsored by the State Council Information 
Office, the State Press and Publication Administration of Radio, China Television Artists Association, Qinghai Provincial Propaganda Department, which was first and only documentary festival with mountain theme in 2008 . Its purpose was to further enhance the world's attention on civilization of the mountain , promote harmony between man and nature, realize dialogue and communication from diverse cultures. Each festival issues "Jade Kunlun" award.

The first exhibition collected 340 works, which designed 21 awards from humanities, natural and social three categories in 2008. The second exhibition's subject was "mountain nation, native images, continuation and spread of human memory" in 2010. 511 works from 35 countries were collected in primaries. The third exhibition considered "Recording and witness: the real image of the human in world of mountain" as the theme in 2012. [3] 545 works from 36 countries participated in primaries. Seven events were wonderful and abundant. The fourth festival, with the theme of "survival memories of mountain ethnic and the edge image saved", provided a platform for the exchange of different regions' cultures. "mountain" was well emphasized by China ( Qinghai ) World Mountain Documentary festival. Firstly, mountain nation's survival style was mysterious because of exotic features and pastoral charm, which was not industrialized. Secondly, harmony between man and nature in mountain National simple life, become a model for contemporary ecological aesthetics. Thirdly, Mountain's natural landscape without damaged by industry, was a natural studio.

Around the mountain's landscape, China ( Qinghai ) World Mountain Documentary Festival, focusing on" ecological concept ", leaded documentary to pursue ecological culture .This is more mature cultural reflection.

\subsection{2、 Market operations : the core of China (Guangzhou )} International Documentary Festival

China ( Guangzhou ) International Documentary Festival was co-sponsored by the State Press and Publication Administration of Radio and Guangdong Provincial
People's Government in 2003. Through 11 years, it achieved a upgrade change from a symposium, documentary general meeting to the documentary festival. 11 years ago, there were more than 100 works from 14 countries. Now, it is accredited as a unique professional documentary festival domestic and abroad. There were 2071 works from 72 countries in 2014.Guangzhou government operated this exhibition from 2003 to 2011. And then, Ruidu International Cultural Communication institutions ,a well-known public relations agency, has been co-ordinating from 2012. This agency has been responsible for funding, market development, organization and management, and so on. During two years of market operation, it has formed a professional system, including selection of awardeded works, market trading, trade exchange, professional forum, international training and public broadcasting. It has developed characterized in internationalization, industrialization and market characteristics. The core of its transactions includes buyers meet, demand reports in the international market, introduction and sale for finished documentary, and documentary's pre-sale program. [4]

\subsection{Position of China Jiayuguan International Short Film Festival}

Domestic documentary film festival is being started from content themes, shooting idea, to market operation, while oversea documentary film festival has been in motion since 1955 .

But the awareness of occupying market segments and fostering cultural characteristic is very clear.

2.3.1 Silk Road 's historical background and international perspective

"Silk Road" in Gansu is 1600 kilometers long, from Tianshui to Dunhuang, during more than 10 dynasties, over 1000 years. New Silk Road economic belt proposed in 2013, is economic development regions based on the concept of the ancient Silk Road. It is a " economic corridor" which connected with the Asia-Pacific Economic Zone and the European Economic Circle. In the documentary field, both thousand years history and 
international exchanges of Silk Road and international perspective of New Silk Road, are rich topics. They offer a unique life, fresh policy, spiritual beliefs. In the resurrection of a new "Silk Road" process, it is important to change " cultural resources " to "cultural goods", change " cultural relics " to "cultural living state ".Now, documentary images as modern means, give a comprehensive explanation of local culture, offer new opportunity to spread.

2.3.2 Theme and Aesthetic Features of Chinese Western Culture

Natural scenery, Folk matters, Character of Chinese Western Culture, has became internal ethos and unique cultural quality of China Jiayuguan International Short Film Festival.

Recent snow-covered plateau recorded Tibetan people's vitality under difficult conditions.

Desire of Long Lake recorded a tear-jerking story that people in Wuwei and Minqin had controlled deserts, and brought ecological thinking about harmony between man and nature.

Human is peak of mountain. Natural landscape's crude and stalwart feature highlights the powerful human feelings. Chang Shuhong in Gansu Zhangye, unknown artist and heritage protector in Dunhuang, they all have stayed Dunhuang in all life. Chinese western people highlight the spirit of the plateau.

\section{Development Trend of China Jiayuguan International Short Film Festival \\ 3.1 Cultural attribution : History gifts of Chinese Civilization Innovation Zone}

In the late 1980s and early 1990s, Chinese documentary began to move toward the world.

Chinese Western documentary has begun targeting and impacting international awards.

Anthropological documentary with ethnic minorities theme get a good international reputation. China Yao Won a best documentary award in the Tenth International Anthropological Film in 1996. Baguo north street 16th won Grand Prix of the French Real Film Festival in1997.Miao village Story was nominated in 13th France International Audiovisual Festival in 1999.Wedding won an award in Fifth Romania Stella International Documentary Film Festival in 2000. Finally caravan joined Germany Leipzig 44th International Documentary Film Festival in 2000. Tibet a year has broadcasted in 50 countries. Silk Road and New Silk road, Sino-Japanese co-produced in 1980 and 2006, caused the domestic general public pay attention to Chinese Western documentary.

Dunhuang broadcasted in 2008, has brought the documentary to the era of large film of mass. Then, many Chinese Western documentaries collective appeared, such as Qin Empire(2009) looking changan(2009), Large Qinling (2010). These works won various honors because of its theme on Chinese Civilization. So can not give up culture confidence, don't lose yourself in the market.[5] As Chinese Civilization Innovation Zone, Guansu had the fortunate privilege from the zone to shoot documentaries. Many documentaries ,broadcasted at "Gansu theme day" in China Jiayuguan International Short Film Festival, has strengthen Gansu theme and Chinese western express, reflected cultural identity.

There are 5 kinds. The first is the theme of International school of learning, such as

Dunhuang, Dunhuang calligraphy, Dunhuang fairy. The second is Human ancestor,

such as Fuxi fairy tale, Memorial tablet of the Rebuilding the Wang Mugong in HUI hill

The third is prehistoric ancient human and animal ,such as Mystery Bay earth, Mysterious Chinese pottery, the ancient Yellow River, China Dinosaur survey.

The forth is Natural Environment, such as Desire of Long Lake, Great River Flows westward, the House of Lao Gao in Laolongwan, Yellow River 258.

The fifth is Minority Groups, such as Chinese west minority (Yugurs, Dongxiang, Bonan)

,Recent snow-covered plateau. Chinese culture attribution, become spiritual bloodline of China Jiayuguan International Short Film Festival. 
3.2 Industrial operations: Complete chain in professional documentary production process

Today, documentary market came to be matures more and more. Domestic and international documentary festivals all designed links, just as the film shows, movie awards, summit (forum), copyright trading. These links made festival become a popular entertainment, an authoritative award, an academic Forum, a market transaction. These festivals have strengthen the organic integration of production, education and research, integrate knowledge , ideas and capital.

China Jiayuguan International Short Film Festival has the enormous confidence to develop promotion platform , broadcasting way, market activity. They will highlight the leading role of film and television production company, outstand communication and development of film culture.Gansu government, the British Lion Television, Russia Eurasian Science television and radio company, signed a cooperation shooting agreement with Beijing Bo Jing Culture Communication Co., Ltd. in first festival.Jiayuguan city government signed a cooperation shooting protocol with Hainan record Culture Media Co., Ltd. on Jiayuguan.

\section{CONCLUSIONS}

Thirty or forty production organizations signed a cooperation agreement with each other or achieved cooperation. Gansu non-heritage themes are popular. 80 topics got a scientific argument in second festival. During the existing exhibition practice, it is consensus that market and industry-oriented documentary's themes should be introduced, co-produced and merchandised.

China Jiayuguan International Short Film Festival will be built the new bridge for the development of documentary film industry.

\section{ACKNOWLEDGEMENT}

The source of the project: 2013Youth Fund in Lanzhou Jiaotong University.

Historical conditions and realistic consideration of creation in Gansu revoluti onary theme film and television

\section{References:}

[1] Li Liping. There are 86 documentaries topics issued in Gansu in the first batch. [ol] http://gansu.gscn.com.cn/system/2013/09/26/010463031.s html

[2] Li Na. Chen lian has talked about six cultural construction in Gansu[N] Xin newspaper, January 11,2012

[3]Zhang Xiang. Mountain's call and image's FeastChina ( Qinghai ) World Mountain Documentary Festival Summary[N] Qinghai Daily, August 1,2012

[4]Fu Yan. Going international, industry, market-oriented road- Analysis in development model of China ( Guangzhou ) International Documentary Film Festival[J] Contemporary TV, 2006(11)

[5]Zhou yu. Is Chinese documentary spring coming ? [N] Nanfang Daily, December15,2013 